\title{
PÄÄKIRJOITUS
}

HEIKKI HIILAMO

\section{Koronakriisi on enemmän kuin talouslama}

V uoden 2020 Diakoniabarometrin otsikko oli enteellinen: Aina uuden edessä. Barometrin aineistonkeruu päättyi helmikuussa 2020 eli juuri ennen koronakriisin alkua. Barometrin julkaisemisen aikana seurakuntien diakoniatyö oli mullistunut tavalla, jota kukaan ei voinut etukäteen kuvitella. Diakonia tehtävä auttaa niitä joiden hätä on suurin ja joita ei muutoin auteta laajeni hetkessä valtavan suureksi. Samaan aikaan perinteiset auttamiskeinot kuten asiakkaiden tapaaminen vastaanotoilla, kotikäynnit ja ruokapalvelutilaisuudet tulivat mahdottomiksi.

Toistaiseksi seurakuntien diakoniatyön muutoksesta ei ole saatavissa kovinkaan tarkkoja tietoja. Tiedämme kuitenkin, että digitaalisten välineiden käyttö yleistyi myös diakoniatyössä. Puhelinkontaktit kasvoivat räjähdysmäisesti samaan aikaan kun kasvokkain tapahtuvat kontaktit vähenivät. Ruokapalvelutilaisuuksia korvattiin ruokakassien jakamisella.

On kiinnostavaa ja tärkeää tutkia, miten diakoniatyö reagoi koronakriisiin. Aikaisempi tutkimus on osoittanut 1990-luvun alun laman kiistattomaksi käännekohdaksi seurakuntien diakoniatyössä. Työ alkoi suuntautua vanhuksista työikäisiin; kotikäynneistä, leireistä ja muuta ryhmätoiminnasta vastaanotoilla tapahtuvaan kohtaamiseen. Laman aikana ja pian sen jälkeen kehitetyistä työmuodoista tuli pysyvä osa diakoniatyötä. Muutos ei kuitenkaan tapahtunut samanaikaisesti eikä yhdenmukaisesti. Tämä johtunee seurakuntatyön paikallisesta luonteesta: kukin seurakunta voi melko vapaasti määritellä oman diakoniatyönsä painopisteet. 
Sen sijaan diakoniatyö ei juuri muuttunut vuonna 2008 alkaneen globaalin talousromahduksen jälkeen. Taloudelliseen ahdinkoon joutuneiden auttamiseksi tarkoitetut työmuodot aktivoituivat, mutta suuria muutoksia työtavoissa tai avustusmuodoissa ei tapahtunut. Talouskriisi oli 1990-luvun lamaan verrattuna vähemmän dramaattinen mutta pitkäkestoisempi. Tämä selittäneet laimeampaa reaktiota.

Koronakriisi muistuttaa osin talouskriisiä, mutta on ulottuvuuksiltaan laajempi. Sen vaikutuksia ja siihen liittyviä tarpeita on vaikeampi ennustaa. Taloudellisen avun lisäksi diakoniatyöhön kohdistuu odotuksia myös sosiaalisiin tarpeisiin - esimerkiksi yksinäisyyteen ja mielenterveysongelmiin - vastaamisessa. Koronakriisiin liittyy myös terveydellisiä näkökohtia. Syrjäytymisvaarassa olevat diakonian asiakkaat tarvitsevat tukea ja neuvoja siitä, miten välttää tartuntoja, miten hakeutua testeihin ja miten päästä rokotuksiin. Kokoontumisrajoitukset ja kirkkotilojen sulkeminen ovat saattaneet korostaa myös hengellisiä tarpeita diakoniatyössä.

Edellä sanottu on tärkeää ottaa huomioon tulevissa tutkimuksissa. Samat menetelmät ja aineistot, joita on käytetty talouslamojen ja diakonian tutkimukseen, eivät ole sellaisenaan riittäviä koronakriisin vaikutusten tutkimuksessa.

Lähivuodet näyttävät miten merkittäviä ja pysyviä muutoksia koronakriisi tuo seurakuntien diakoniatyöhön. Tutkimuksella on merkitystä siihen, miten hyvin uusia toimivia työkäytäntöjä tunnistetaan ja miten tehokkaasti niistä levitetään tietoa. 